\title{
GEOMORFOLOGIA DO CAMPO DE INSELBERGUES DE QUIXADÁ, NORDESTE DO BRASIL
}

\section{GEOMORPHOLOGY OF INSELBERG FIELD OF QUIXADÁ, NORTHEAST BRAZIL}

\author{
Rubson Pinheiro Maia \\ Departamento de Geografia, Universidade Federal do Ceará \\ Campus do Pici, Bloco 911, Fortaleza, Ceará, CEP: 60455-760, Brasil \\ E-mail: rubsonpinheiro@yahoo.com.br
}

Marcos Antônio Leite do Nascimento

Departamento de Geologia, Universidade Federal do Rio Grande do Norte Av. Senador Salgado Filho, Natal. Rio Grande do Norte, CEP: 59.072-970, Brasil E-mail:marcos@geologia.ufrn.br

\section{Francisco Hilário Rêgo Bezerra}

Departamento de Geologia, Universidade Federal do Rio Grande do Norte Av. Senador Salgado Filho, Natal. Rio Grande do Norte, CEP: 59.072-970, Brasil

E-mail: bezerrafh@geologia.ufrn.br

Henrique Sampaio de Castro

Departamento de Geografia, Universidade Federal do Ceará Campus do Pici, Bloco 911, Fortaleza, Ceará. CEP: 60455-760, Brasil

E-mail: henrique-sdc@hotmail.com

Antônio Jeovah de Andrade Meireles

Departamento de Geografia, Universidade Federal do Ceará Campus do Pici, Bloco 911, Fortaleza, Ceará, CEP: 60455-760, Brasil

E-mail: antoniomeireles4@gmail.com

Luis Martin Rothis

Departamento de Geologia, Universidad de San Juan Av. Ignacio de la Roza 590, Rivadavia, San Juan, CEP: 5400, Argentina E-mail: amarothis@gmail.com

\section{Informações sobre o Artigo}

Data de Recebimento:

$16 / 12 / 2014$

Data de Aprovação:

22/04/2015

\section{Resumo:}

Ao norte do Maciço da Borborema, no Nordeste Brasileiro, vários campos de inselbergues caracterizam as depressões sertanejas. Esses relevos ocorrem principalmente em áreas de intrusões graníticas que atualmente estão sendo exumadas pela erosão diferencial. Em Quixadá, no estado do Ceará, ocorre um dos mais representativos campos de inselbergues do Brasil. Trata-se de diversas 
Palavras-chave:

Inselbergues; Granito; Fácies;

Fraturas; Etchplanação.

\section{Keywords:}

Inselbergs; Granite; Fácies;

Fracture; Etchplanation.

massas rochosas em geral côncavo-convexas ou fraturadas, formada pela exposição subaérea de um batólito granítico. Nesse trabalho, individualizamos as diversas formas de inselbergues agrupando-as segundo seus padrões morfológicos. Esses padrões foram correlacionados com as fácies do granito e com a densidade de fraturamento. Observamos que as fácies porfiríticas ricas em fenocristais de feldspato originaram inselbergues com feições de dissolução do tipo caneluras e vasques, enquanto as fácies caracterizadas pela presença de diques e enclaves máficos originaram inselbergues caracterizados por feições de fraturamento do tipo taffonis de colapso. Essa correlação nos permitiu concluir que mesmo dentro de uma mesma unidade litológica como o granitoide, as variações faciológicas internas podem resultar em feições distintas de acordo com as características mineralógicas e texturais da rocha e do fraturamento.

\begin{abstract}
:
In the north part of the Borborema Massif, Northeast Brazil, various fields of inselbergs characterize the hinterland depressions. These reliefs occur in areas of granitic intrusions that have been exhumed by differential erosion. In Quixadá, State of Ceará, lies one of the most representative fields of inselbergs. This field is composed of various generally concave-convex, fractured rock masses, formed by subaerial exposure of a granite batholith. In this work, the various forms of inselbergs were classified according to their morphological patterns. These patterns were correlated with granite fácies and fracture density. We observe that fácies rich in porphyritic feldspar phenocrystals originated inselbergs with dissolution features of flute and vasques types, while those characterized by the presence of dikes and mafic enclaves formed inselbergs characterized by collapse taffonis. This correlation allowed us to conclude that even within the same geologic granitoid unit, internal fácies variations may result in different features according to the mineralogical textural and fracturing characteristics of the bedrock.
\end{abstract}

\section{Introdução:}

Os campos de inselbergues constituem uma das mais interessantes formas das paisagens tropicais (PEPIT, 1990). Trata-se de massas rochosas em geral côncavo-convexos isoladas ou agrupadas (GOUDIE, 2004) ao longo de lineamentos estruturais resultantes da erosão diferencial (OSBORNE, 1985). Comumente inselbergues apresentam escarpas íngremes, fato que impossibilita a permanência da alteração superficial resultando no afloramento contínuo do embasamento. A ocorrência de tais campos é comum em climas áridos e semiáridos (MATMON et al., 2013), mas sua origem está associada a sistemas erosivos associados ao ambiente tropical e subtropical (ROMER, 2007), onde o intemperismo profundo originou espessos regolitos (GOUDIE, 2004) cujo a remoção ocorrerá em climas mais secos (MATMON et al., 2013).

Quanto à evolução geomorfológica, os trabalhos que discorrem sobre a origem e desenvolvimento de inselbergues, comumente utilizam conceitos de downwearing e etchplanação (EBERT e HÄTTES-
TRAND, 2010) ou pelo recuo paralelo de escarpas e pedimentação (KING, 1956). Esses conceitos concentraram grande parte das discussões acerca da evolução de paisagens graníticas em climas secos a partir de uma ênfase morfoclimática. Atualmente as concepções de duplo aplainamento têm sido utilizadas para explicar a exumação e exposição do embasamento em superfície (TARBUCK and LUTGENS, 2006), pois cada vez mais, têm se reconhecido que os componentes que regem a evolução associada aos campos de inselbergues estão relacionados a processos que ocorrem na base do regolito e não apenas em superfície (TWIDALE, 2002). Dessa forma, os inselbergues constituem um remanescente de erosão que pode fornecer informações importantes sobre a evolução geomorfológica dos terrenos em que ocorrem (MATMON et al., 2013).

No Nordeste setentrional brasileiro, vários campos de inselbergues ocorrem na porção norte do Maciço da Borborema. São eles os campos de inselbergues de Patos na Paraíba, na região do Seridó no Rio Grande do Norte e de Quixadá no Ceará (Figura 1). 


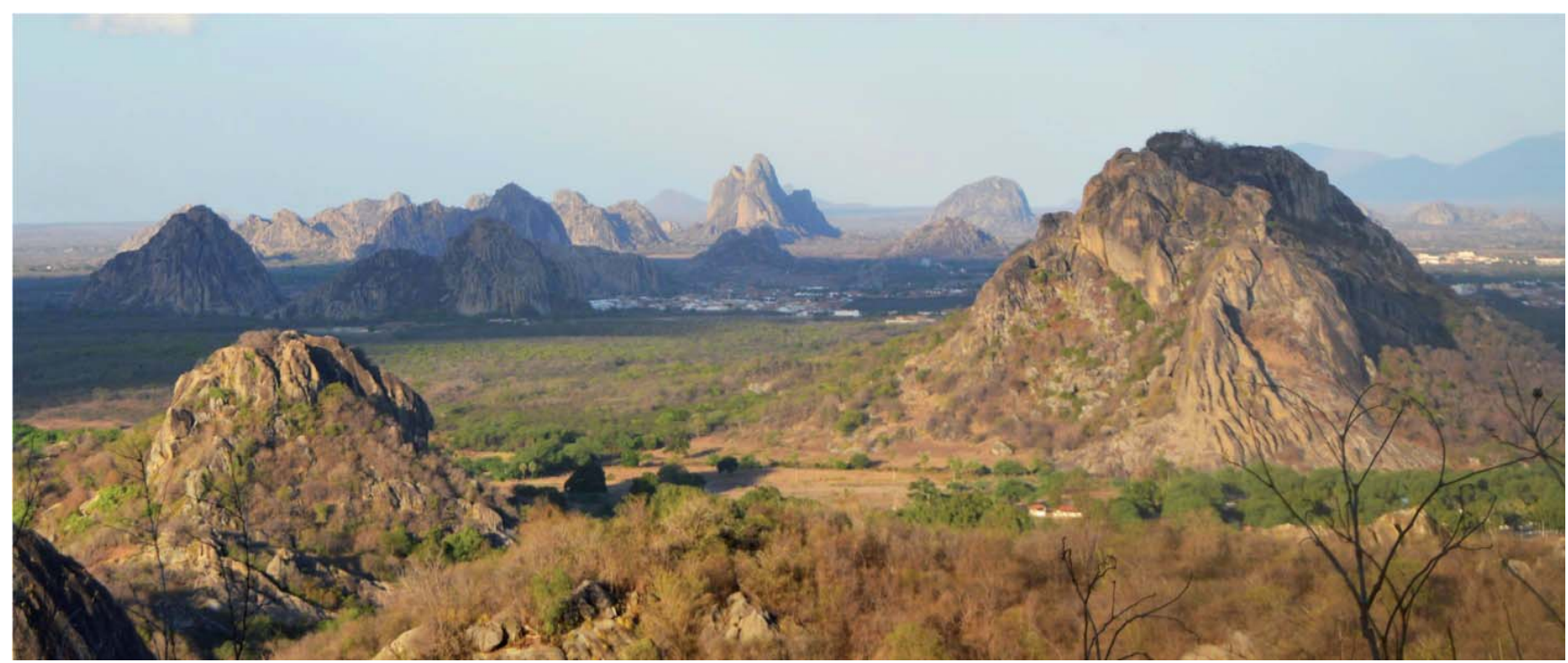

Figura 1 - Campo de Inselbergues de Quixadá no Ceará (Foto: Maia, 2014).

Todas essas ocorrências estão associadas a um embasamento ígneo, resultante de intrusões graníticas que afetaram a Província Borborema a partir de várias orogenias que ocorreram no Pré-Cambriano.

Trabalhos abordando diferentes aspectos da geologia de Quixadá foram elaborados por Torquato et al. (1988) e de ênfase geoquímica por Almeida et al. (1999). Esses trabalhos descreveram as diferentes fácies do embasamento em âmbito regional, permitindo diferenciar em termos gerais os padrões de relevo segundo seu controle litológico. Contudo, não há trabalhos que discorram sobre a geomorfologia de Quixadá com ênfase no papel exercido pelas características estruturais conforme preconiza a teoria de duplo aplainamento e Echplanação de Budel (1982), mundialmente consagrada como principal modelo de evolução para paisagens caracterizadas por campos de inselbergues.

Nesse sentido, o presente artigo propõe uma análise acerca do desenvolvimento do campo de inselbergues de Quixadá - CE, a partir de seu condicionamento geológico e sobretudo estrutural. Para tanto se baseará na literatura especializada acerca da variabilidade faciológica dos plútons graníticos e de suas respectivas características estruturais, como os padrões de fraturamento e lineação. A análise acerca da evolução de paisagens graníticas em ambientes submetidos à alternância climática basear-se-á nos conceitos de etchplanação de Budel (1982) considerando aspectos estruturais da morfogênese atual que apresenta clima semiárido com predomínio da meteorização termoclástica.

\section{Localização}

O setor de estudo está localizado no município de Quixadá na parte central do estado do Ceará, região nordeste do Brasil, mais precisamente no setor setentrional do batólito Quixeramobim/Quixadá (Figura 2).

Nesta área ocorrem amplas exposições do embasamento cristalino na forma de lajedos, maciços e inselbergues. Sua geologia é caracterizada pela ocorrência de um corpo intrusivo granitóide circundado por rochas encaixantes que compõem o complexo gnaisse-migmatíco (Figura 2). Esse complexo gnáissico-migmatítico compreende o embasamento é composto por gnaisses, migmatitos, anfibolitos, granulitos e rochas cálciosilicáticas (TORQUATO et al., 1989).

\section{Métodos}

Utilizou-se nesse trabalho a análise de informações geológicas e geomorfológicas em ambiente SIG, a partir da correlação entre as folhas Quixadá (SB.24-VB-VI), Quixeramobim (SB.24-V-D-III), o mapa de litofácies do complexo granítico Quixadá-Quixeramobim, elaborado no âmbito do projeto Granitoide do Ceará por Torquato et al. (1989), dados de SRTM e descrições petrográficas e suas relações com as principais feições de relevo. Essa correlação permitiu associar as formas de relevo, seus padrões e densidade de ocorrência com as fácies e com os padrões de fraturamento do Batólito Quixadá, bem como correlacionar o relevo do referido batólito com o que ocorre no embasamento encaixante. 


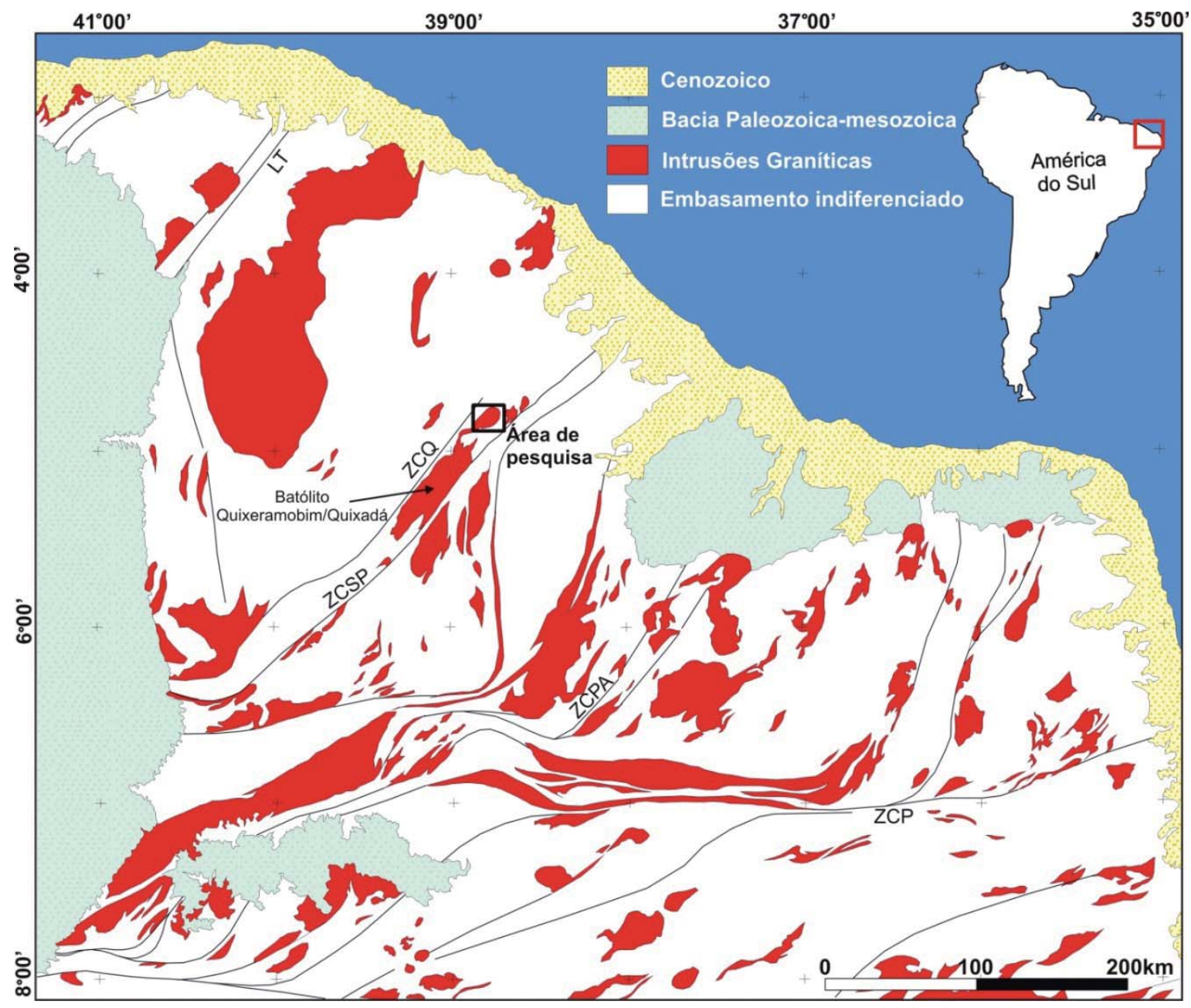

Figura 2 - Geologia simplificada do Nordeste Brasileiro com ênfase nas intrusões brasilianas. LT-Lineamento Transbrasiliano, ZCQ - Zona de cisalhamento Quixeramobim, ZCSP - Zona de cisalhamento Senador Pompeu, Zona de cisalhamento Portalegre, ZCP - Zona de cisalhamento Patos. (Elaborado a partir de edição de Shape de Geologia do NE Brasileiro - CPRM, 2003).

Os trabalhos de campo e reconhecimento objetivaram a identificação e caracterização das macro e micro formas de relevo. A identificação de micro formas como Taffonis, Vasques-Gnamas, Caneluras e Lajedos subsidiaram, junto à bibliografia de paisagens graníticas, a análise geomorfológica dos níveis de dissecação do batólito granítico.

Esse trabalho contou ainda com o Processamento Digital de Imagens de composições coloridas utilizando-se de bandas espectrais do Sensor TM - Landsat 5 . Essas composições subsidiaram a elaboração de um mapa de lineamentos objetivando estabelecer conexões entre geomorfologia, controle estrutural, e a direção NE-SW das zonas de cisalhamento Quixeramobim e Senador Pompeu. Os blocos diagramas deram suporte a interpretação geomorfológica e a representação tridimensional acerca da evolução do relevo.

\section{Caracterização Geológica e Geomorfológica da Área de Estudo}

A grande maioria dos corpos graníticos no nordeste setentrional brasileiro está associada às zonas de cisalhamento brasilianas (Figura 2) (ALMEIDA e ULBRICH, 2003). Estas zonas de cisalhamento são condutos por onde pode circular um grande volume de fluidos (TRINDADE et al., 2008). Assim, um grande número de granitos orogênicos é interpretado como resultado da intrusão em regiões extensionais associadas às estruturas tectônicas locais e regionais (NEVES, 2012). Na Província Borborema essas estruturas são representadas principalmente por zonas de cisalhamento de direção NE-SW e E-W (VAUCHES et al., 1995). Especificamente, na área de pesquisa, as intrusões resultam da ascensão de magma através da crosta ao longo de zonas de cisalhamento extensionais (CASTRO 
et al., 2002) principalmente às zonas de cisalhamento Quixeramobim e Senador Pompeu (NOGUEIRA, 2004) (Figura 2). Vários exemplos de intrusões ao longo de zonas de deformação podem ser encontrados no setor setentrional da Província Borborema, ao norte do lineamento Patos (Figura 2) (VAN SCHMUS et al., 1995). Essas intrusões ocorreram no decorrer da Orogênese Brasiliana (ARTHAUD, 2007) resultante da colagem tectônica Brasiliana/Panafricana (BRITO NEVES et al., 2000), a qual foi acompanhada de um importante plutonismo granítico de 585 Ma (FETTER, 2000). Durante a orogênese Brasiliana inúmeros corpos graníticos intrudiram a crosta continental, evidenciando o climax do evento orogenético e magmático (MAGINI \& HACKSPACHER, 2008).
A ascensão de magma ocorreu no interior da crosta continental originando os batólitos que foram exumados pela dissecação e erosão do embasamento encaixante sotoposto. A esse respeito, Silva (1989) concluiu que a cristalização das rochas graníticas de Quixadá ocorreu sobre pressões litostáticas de 6 a 8 kbar que equivalem a profundidades crustais entre 25 e $30 \mathrm{~km}$. Dessa forma os granitos apresentam em sua maioria uma textura porfirítica monzonítica nucleadas por enclaves máficos (ALMEIDA, 1995).

O embasamento encaixante na região de Quixadá (CE) corresponde ao complexo Gnáissico-Migmátitico indiferenciado que ocorre ao redor do Complexo Granítico, ocupando cerca torno de $90 \%$ do volume das encaixantes (Figura 3).

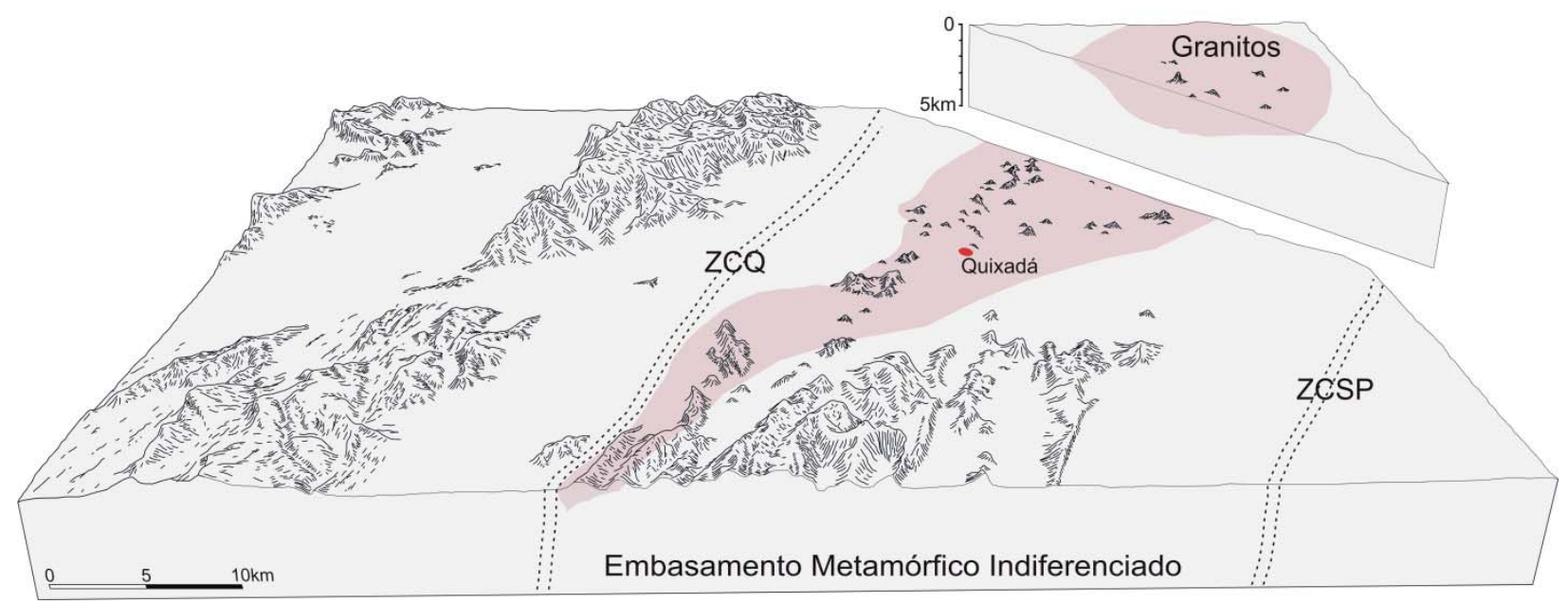

Figura 3 - Bloco Diagrama Geológico-Geomorfológico de Quixadá e adjacências (ZCQ - Zona de cisalhamento Quixeramobim. ZCSP - Zona de cisalhamento Senador Pompeu). Morfologia de subsuperfície do batólito granítico baseada em Castro et al. (2002).

Os processos intempéricos atuantes estão subordinados a semiaridez, com clima do tipo Semiárido (NIMER, 1989), que se caracteriza pela predominância das altas temperaturas associadas a um regime de chuvas esporádicas, concentradas principalmente nos quatro primeiros meses do ano. Segundo Nimer (1989), o clima semiárido é influenciado pela zona de convergência intertropical, com período seco de junho a janeiro e úmido de fevereiro a maio. O sistema de chuvas é controlado principalmente por diversos mecanismos as quais se destacam as frentes frias, a posição da Zona de Convergência Intertropical (ZCIT) e dos Vórtices Ciclônicos de Ar Superior (VCAS) e as ondas de leste (NOBRE, 1994). A precipitação pluviométrica média é em torno de 700 mm anuais e a temperatura em torno de $27^{\circ} \mathrm{C}$, com mínima de $21^{\circ} \mathrm{C}$ e máxima de $36^{\circ} \mathrm{C}$. A umidade relativa do ar ao longo do ano na região é em média $70 \%$ e acompanha a curva de precipitação pluviométrica, com maiores valores observados de fevereiro a maio e valores menores de junho a janeiro (INMET, 2014).

Quanto a vegetação nos inselbergues, sítios de crescimento, que são microclimaticamente e edaficamente secos, se desenvolvem e sustentam uma vegetação altamente especializada (POREMBSKI, 2007). A vegetação predominante é caatinga arbustiva com predomínio de angiospermas (GOMES e ALVES, 2009) e os solos em sua maioria ocorrem em associações de Planossolo Nátrico e Neossolos Litólicos com dispersas ocorrências de Vertisolos nas áreas mais rebaixadas (BRASIL, 1981). 


\section{Resultados}

Na área de pesquisa, verifica-se que o padrão de lineamentos possui a direção principal NE-SW estando estes relacionados às zonas de cisalhamento Quixeramobim e Senador Pompeu. No interior do batólito os lineamentos são menos expressivos quando comparados com a densidade de lineamentos na área circunjacente do embasamento encaixante (Complexo Gnaissico-Migmatítico.). Tal fato corrobora o trabalho de Nogueira (1998), que revelou que na parte central do batólito os efeitos da deformação foram menos intensos, apresentando dessa forma uma incipiente foliação. Essa foliação fora desenvolvida em estado magmático e possui orientação em geral paralela a orientação geral das zonas de cisalhamento (NE-SW), que controlaram o alojamento do plúton (NOGUEIRA, 2004).

A análise de lineamentos na área do batólito Quixadá indica que a maior concentração de feições lineares NE-SW e NW-SE coincidem com áreas com maior espaçamento entre os inselbergues. Isso sugere uma maior erosão associadas a essas áreas, condicionada pelos trends estruturais que favoreceram a dissecação. Os lineamentos são representados principalmente por pequenos baixos topográficos na forma de pequenas drenagens de $1^{\circ}$ ordem sem padrão hidrográfico aparente. A figura 4 mostra a relação entre o trend de lineamentos regionais e a distribuição de inselbergues no âmbito do batólito granítico Quixadá.

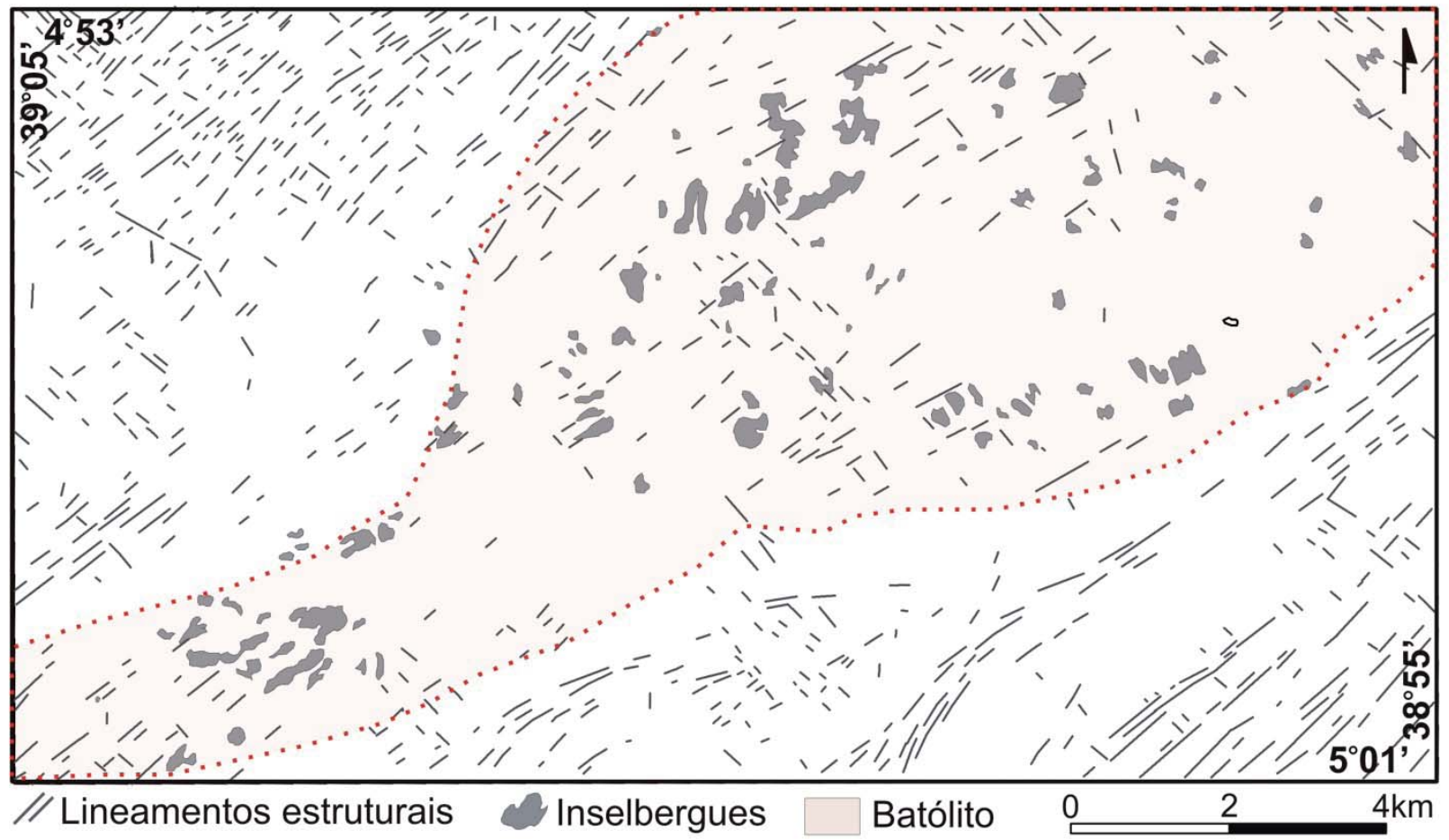

Figura 4 - Relação entre a distribuição dos inselbergues e os lineamentos estruturais.

Nos setores mais fraturados, a meteorização é facilitada, possibilitando uma alteração progressiva e mais intensa quando comparada a setores menos fraturados. Desse modo a densidade de inselbergues pode refletir o grau de fraturamento do maciço rochoso. A maior densidade de fraturas pode conduzir a uma maior dissecação originando feições mapeáveis do tipo lineamentos estruturais.

O papel exercido pelas juntas resultou na erosão diferencial que distinguiu o batólito segundo sua densidade do fraturamento. Pode-se constatar que a maior ocorrência de inselbergues está relacionada aos núcleos granitoides com as menores densidades de fraturas, o que possibilitou sua manutenção como afloramento.

Associado a esse contexto, o quadro paleoclimático pode contribuir sobremaneira para a erosão diferencial e consequentemente a exumação. Isso implica, entre outras coisas, que o substrato de subsuperfície aparecerá em superfície, porque as fases pedogênicas associadas às morfogênicas alteram e removem, respectivamente, os níveis crustais mais rasos evidenciando estruturas mais profundas como os batólitos (Figura 5). 
Quando exumada, a superfície interna de um corpo granítico, definida pela estrutura que se encontra afetada por processos de meteorização, é muito maior que a correspondente na superfície externa alterada, habitualmente restringida à parte superior do Batólito. $\mathrm{O}$ principal resultado da meteorização é a perda da coesão granular da rocha, permitindo assim a evacuação dos detritos friáveis (VIDAL ROMANÍ e TEMIÑO, 2004).

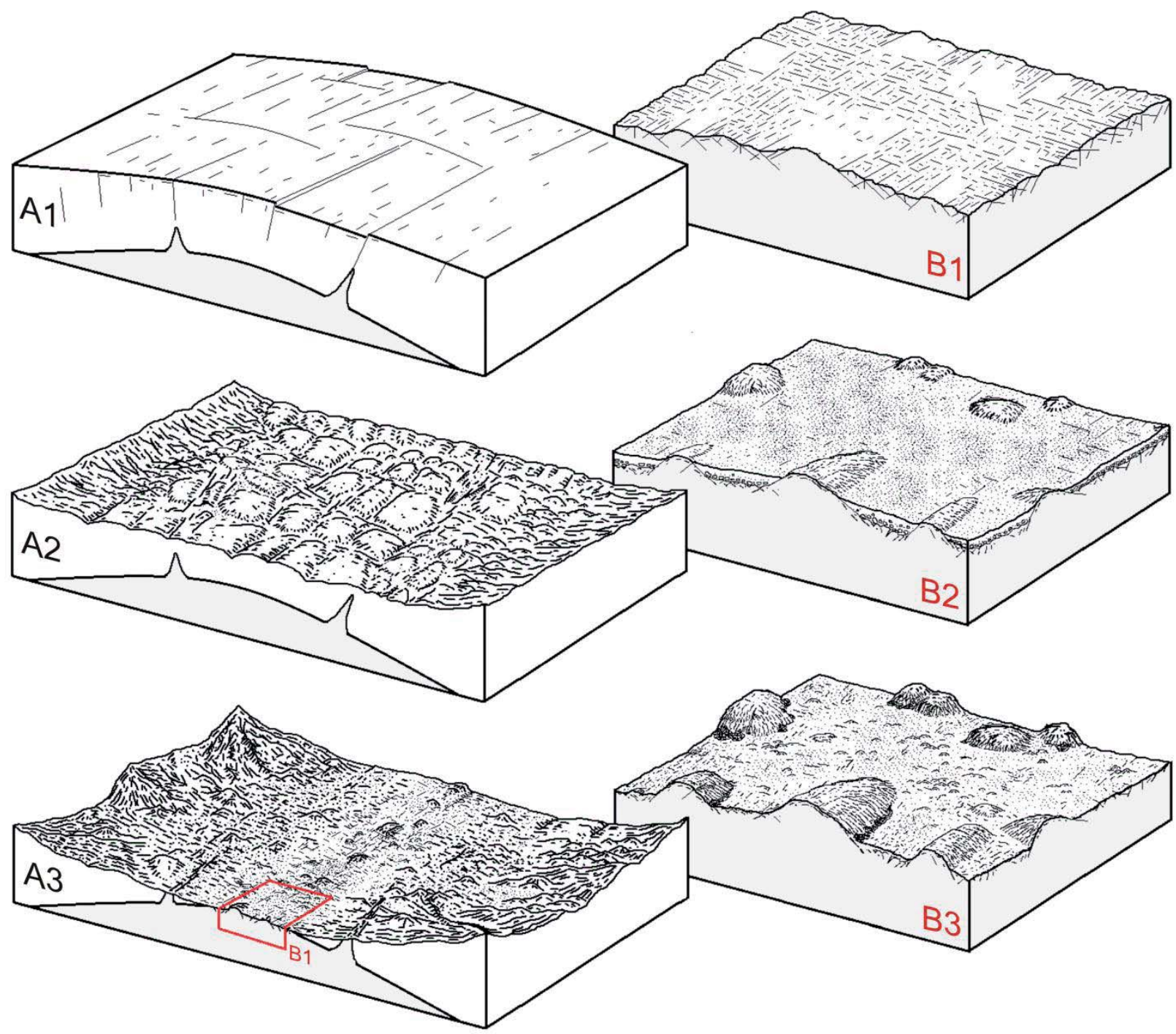

Figura 5 - Erosão diferencial e exumação dos batólitos. A1 - O magma ascende e exerce pressão sobre a crosta sobrejacente produzindo fraturamento. A2 - Fraturas condicionam os processos erosivos intensificando a dissecação. A3 - Formação de uma depressão circundada por relevos residuais que possibilita o afloramento do batólito. B1 - Superfície do batólito exumada. B2 - As fraturas facilitam o processo de intemperização superficial originando um manto de alteração. B3- Em uma fase erosional o manto de alteração é removido expondo as irregularidades do embasamento originando os inselbergues. As etapas B1, B2 e B3 basearam-se no modelo de Etchplanação de Budel (1982).

Isso resulta no contínuo afloramento do embasamento expondo as irregularidades na distribuição das fraturas na forma de sobressaltos topográficos. Esses sobressaltos do embasamento constituem os inselbergues que resultam da ação conjunta da alteração superficial diferencial segundo a densidade do fraturamento associada à susceptibilidade química a alteração. Dessa forma a diferenciação de fácies associadas à trama estrutural favorece uma meteorização seletiva que resultará em mantos de alteração de espessura diferenciada. Esse contexto associado a variabilidade climática favoreceu a remoção do manto de alteração originando os insel- 
bergues. Estes por sua vez, refletiram em suas formas, a preponderância de seu fator genético mais significativo seja de ordem geoquímica para as fácies mais solúveis, seja de ordem física no caso dos inselbergues que evoluem por intemperização termoclástica.

Na área de estudo foi possível distinguir a ocorrência de 3 tipos de inselbergues segundo suas características morfogenéticas. Essa proposta de individualização baseia-se na ocorrência de feições erosionais derivadas da dissolução, do fraturamento ou a ausência de ambas. Especificamente no que concerne a formação de feições erosionais, observou-se que esta associação pode ser feita a partir de uma correlação litológica e faciológica dentro de uma mesma unidade litológica.

Os 3 grupos de inselbergues identificados podem ser assim organizados: 1 - Feições de dissolução, 2 Feições de fraturamento, 3 - Maciços.

Os inselbergues do grupo 1 possuem as menores altitudes e são os que possuem mais feições de dissolução do tipo vasques, gnamas e caneluras. Nesses inselbergues, não há feições de fraturamento e as de escamação são pouco aparentes. Normalmente ocorrem

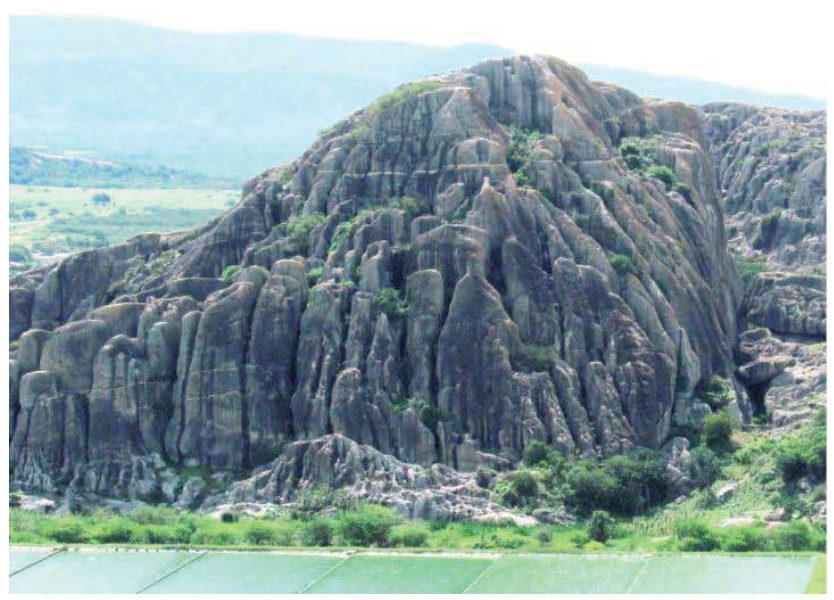

fácies graníticas porfiríticas ricas em fenocristais de feldspato bem desenvolvidos com uma matriz micácea do tipo fanerítica (Figura 6).

As feições de dissolução associadas a esses inselbergues devem-se a sua composição. Neste caso a solubilidade da biotita especificamente nos enclaves máficos e dos fenocristais de Feldspato. O menor teor de biotita associado a esses casos confere uma maior coesão física da rocha a intemperização termoclástica. Desse modo inselbergues do tipo 1 podem ser caracterizados por sua morfologia convexa associada a dissolução e por não exibir feições erosionais resultante do fraturamento ou da escamação bem desenvolvidas. Nas escarpas desenvolvem-se uma densa rede de dissecação representada por feições de dissolução tipo caneluras contínuas ou intercaladas por níveis escalonados de bacias de dissolução do tipo vasques. O ponto de partida para a formação de feições de dissolução são os enclaves máficos associados aos granitos. Nesses enclaves ocorre um aumento pontual na proporção de biotita em relação ao feldspato resultando em uma dissecação mais intensa que encaixa a rede de drenagem originando a canelura (Figura 6 B).

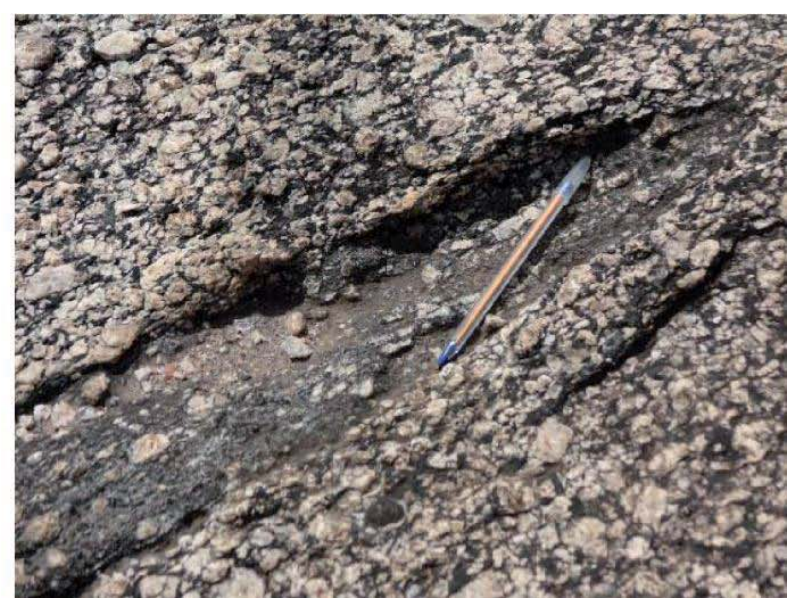

Figura 6 - Foto A - Inselbergue do tipo 1, com feições de dissolução tipo caneluras. Foto B - Enclave elipsoidal máfico em granito porfirítico caracterizado por fenocristais de feldspato (Fotos: Maia, 2014).

Os inselbergues do tipo 2, caracterizam-se pela densidade de fraturamento. Nesses casos as feições que melhor caracterizam esses inselbergues estão relacionadas ao desmembramento do corpo rochoso e ao colapso de blocos. Esses inselbergues não são passíveis de classificação segundo padrões de concavidade ou convexidade exibindo uma morfologia caótica resultante sobretudo da meteorização termoclástica e da esfoliação (Figura 7). Nos setores mais íngremes, as feições de esfoliação originam taffonis de colapso. Os blocos desprendidos pela esfoliação colapsam e originam depósitos rudáceos do tipo caos de blocos na base das escarpas do inselbergues.

A predisposição ao fraturamento nos inselbergues do tipo 2 está associada a ocorrência de enclaves/diques que condicionam a propagação de fraturas termoclásticas. A presença desses diques resulta da injeção de magma em diferentes estágios da cristalização. A esse 

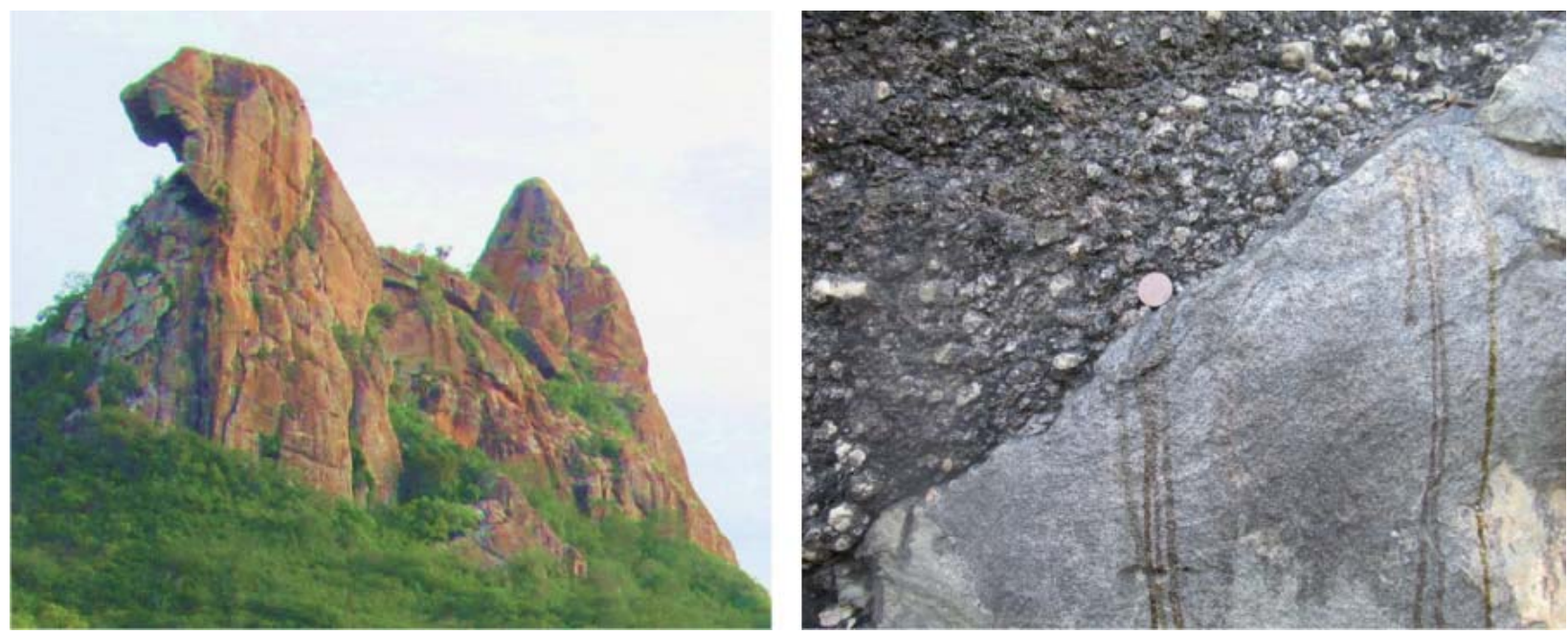

Figura 7 - 1 Foto: Inselbergue do tipo 2, com feições de fraturamento. 2 Foto: Dique de composição granítica cortando a fácies principal (monzonito) do Batólito de Quixadá (Fotos: Maia, 2014).

respeito Jacobs (2012) considerou que se o magma é injetado na rocha cristalizada, este magma é canalizado para as fraturas precoces da rocha granítica quase sólida e interage com os últimos líquidos magmáticos apenas localmente para formar diques compostos ou fragmentados. Já a granulação mais fina destes, indica um rápido resfriamento devido ao contraste de temperatura com a rocha hospedeira.

O terceiro grupo de inselbergues exibe escarpas maciças sem feições de dissecação aparente. Não há feições erosionais de dissolução significativas como caneluras, vasques e taffonis nem de fraturamento como disjunção esferoidal ou escamação. Esses inselbergues ocorrem principalmente fora da área do batólito, ao sul e são associados ao embasamento encaixante do complexo Gnaissico-Migmatítico. Trata-se de inselbergues de escarpas íngremes, com morfologia convexa (Figura 8). Como ocorrem fora da área do batólito, estão orientados segundo a direção estrutural das Zonas de cisalhamento Senador Pompeu e Quixeramobim de direção NE-SW.

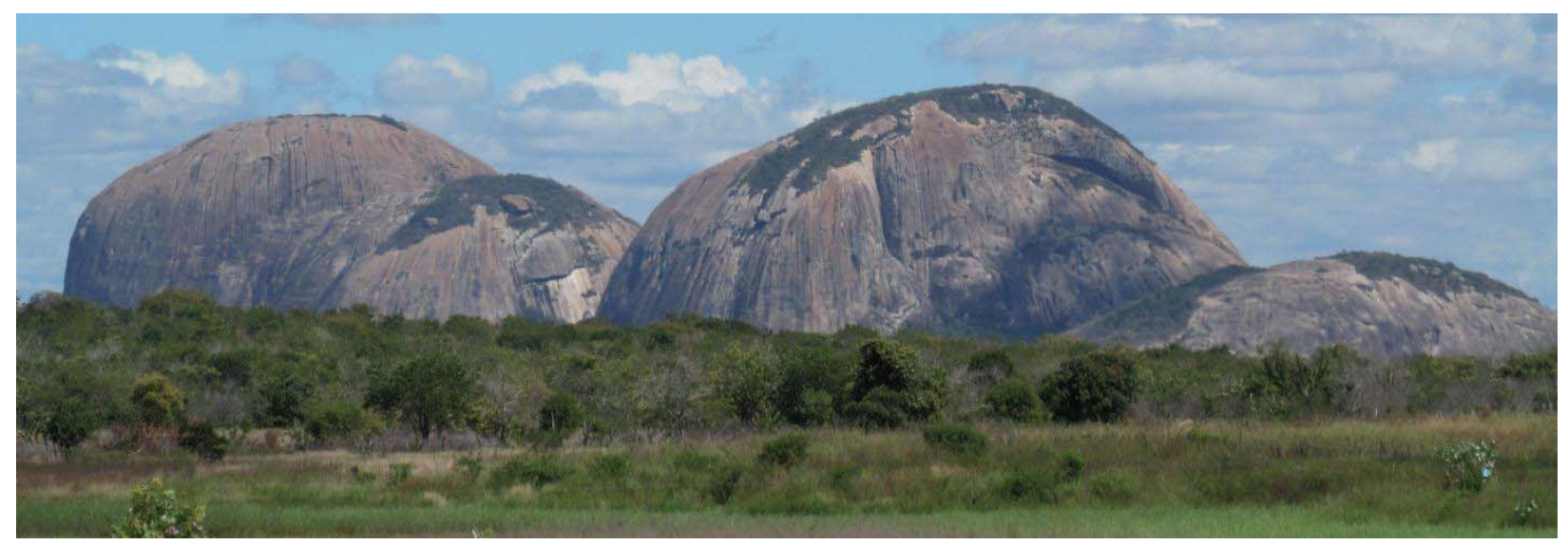

Figura 8 - Inselbergues do tipo 3, sua ocorrência está associada ao embasamento encaixante do complexo GnaissicoMigmatítico, nos arredores imediatos da área de ocorrência do plúton granítico Quixadá (Foto: Maia, 2014).

\section{Discussões}

Os inselbergues do Nordeste Brasileiro tiveram suas explicações associadas a uma origem erosiva e residual sob a luz das teorias geomorfológicas clássicas. Contudo, a partir da concepção de duplo aplainamento, verificou-se que os inselbergues, inclusive os da Borborema, localizam-se em áreas menos fraturadas ou mineralogicamente mais resistentes do embasamento (CORRÊA et al., 2010). Especificamente, as descrições do relevo desenvolvidas 
em Quixadá por Torquato et al. (1989) explicaram a gênese e evolução dos inselbergues utilizando-se do modelo de pediplanação a partir do controle litológico.

A esse respeito, Goudie, (2004) atestou que existem relativamente poucos casos em que os inselbergues ocorrem apenas por controle litológico, onde a base das escarpas coincide com um limite litológico. Assim a origem dos inselbergues não estaria relacionada somente as diferenças de composição mineralógica entre o morro e a planície circunjacente, mas sobretudo por um controle estrutural por fraturamento. Assim, os contrastes de composição ou densidade de fraturas são suficientes para iniciar diferenças nos padrões de intemperismo e erosão resultando na formação de inselbergues (TWIDALE e VIDAL ROMANI, 1994).

Especificamente as descrições acerca da geomorfologia de Quixadá realizadas por Torquato et al. (1989), basearam-se no modelo de superfícies de erosão escalonadas elaboradas a partir das mudanças climáticas cenozoicas. Nesse modelo, a ideia de que o relevo do nordeste brasileiro teria evoluído a partir de paleosuperfícies escalonadas foi amplamente difundida por Ab’ Sáber (1969), Andrade e Lins (1965), Mabesoone e Castro (1975), Bigarella (1994, 2003), entre outros. Estes autores reconheceram a existência de várias paleosuperfícies resultantes de fases de aplainamento decorrentes de processos erosivos, dados a partir do soerguimento de um núcleo continental. Segundo o referido modelo, esse soerguimento teria ocorrido na forma de epirogenias pós-cretáceas e foram acompanhadas por fases de dissecação e pediplanação conduzidas por climas secos (MAIA et al., 2010).

A Figura 9 apresenta a compartimentação geomorfológica da área de estudo em níveis de pedimentos escalonados. Essa compartimentação foi apresentada por Torquato et al. (1988) e baseia-se na classificação de King (1956) elaborada para a geomorfologia do Brasil oriental.

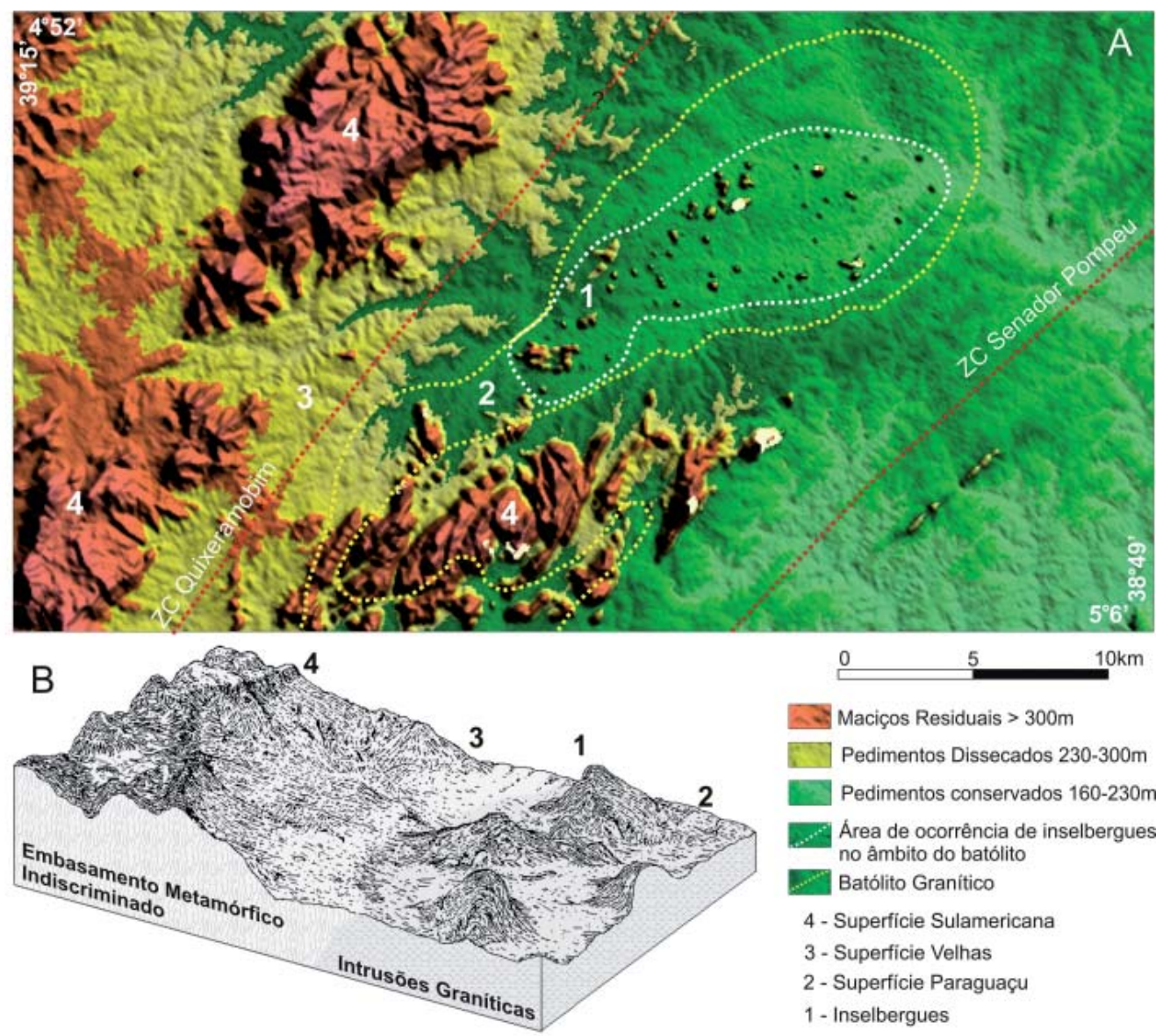

Figura 9 - Compartimentação geomorfológica segundo o modelo de paleosuperfícies escalonadas. A - Reclassificação de imagem SRTM de acordo com os níveis escalonados do relevo. B - Bloco diagrama representando os Maciços residuais, a depressão sertaneja, os inselbergues e a relação destas unidades do relevo com seu controle litológico. Níveis pedimentados baseados em Torquato et al. (1988) e paleosuperfícies em King (1956). 


\section{Geomorfologia do Campo de Inselbergues de Quixadá, Nordeste do Brasil}

A respeito desse modelo, um ponto que merece relevância seria a dificuldade em estabelecer a identificação e sobretudo correlação das paleosuperfícies. O princípio de relevo escalonado com superfícies cada vez mais antigas a medida que se desloca em direção ao topo, não é aplicável extensamente no Nordeste Brasileiro (MAIA et al., 2010). Isso porque o modelo não incorpora os efeitos locais da tectônica cenozoica (PEULVAST e CLAUDINO SALES, 2004) que pode originar maciços elevados como resultado do soerguimento. Exemplos de maciços soerguidos foram demonstrados por Gurgel et al. (2013) no maciço do Pereiro e por Morais Neto et al. (2008) nos maciços de Portalegre e Martins. Esses trabalhos demonstraram os efeitos pontuais da tectônica cenozoica inviabilizando o modelo de paleosuperfícies escalonadas, uma vez que as idades das superfícies soerguidas não coincidiam com aquelas apontadas tradicionalmente. Tal fato pôs em dúvida a confiabilidade de se estabelecer a idade de uma superfície baseando-se na topografia.

Dessa forma, optou-se nesse trabalho pela utilização da teoria de duplo aplainamento de Budel (1982) que envolve dois estágios. O primeiro é definido pelo controle estrutural que possibilita a maior ou menor meteorização da base do regolito. O segundo ocorre a partir da evacuação do manto de alteração expondo o embasamento e originando assim a etchforma (TWIDALE e VIDAL ROMANI, 1994).

O conceito de etchplanação de Budel (1982), vem sendo aplicado para as áreas tropicais que apresentam sazonalidade e pode subsidiar a interpretação geomorfológica acerca dos inselbergues do ambiente tropical. Segundo o modelo da etchplanação, durante os períodos úmidos há o aprofundamento da alteração, enquanto que a erosão superficial ocorre com maior intensidade durante a estação seca, promovendo a planação e, em alguns casos, expondo o front de alteração. Desse modo, compreender a evolução geomorfológica do campo de inselbergues de Quixadá é compreender como ocorrem os mecanismos de exumação do batólito através dos ciclos erosivos e como estes são influenciados pela trama estrutural vigente.

De acordo com Vitte (2005), a origem dos inselbergues está associada às características do substrato, associado às propriedades geoquímicas das rochas que induz ao aumento da intensidade do intemperismo químico, viabilizando a ação morfogenética por meio dos processos fluviais e movimentos de massa. Esses movimentos de massa promovem o abaixamento do relevo em rochas pouco competentes e as mais resistentes permanecem como sobressaltos topográficos. Para tanto, a alternância entre a alteração geoquímica das rochas e a erosão superficial através da variabilidade climática (BIGARELLLA, 2003) faz com que os períodos mais secos ocorram ciclos erosivos com a exposição do saprólito. Este por sua vez apresenta topografia irregular que através da erosão vai sendo exumado por meio da remoção dos grãos de textura mais fina, evidenciando assim os inselbergues.

A extrema instabilidade climática ocorrida durante o Pleistoceno imprimiu na paisagem modelos de evolução distintos e sucessivos, sendo a alternância entre fases úmidas e secas, a característica fundamental desse período (Figura 10) (BIGARELLA, 2003). No Nordeste Brasileiro, o quadro fitogeográfico, principal reflexo do clima, teve sua vegetação de caatinga expandida e retraída por diversas vezes no Pleistoceno (CAVALCANTE, 2005).

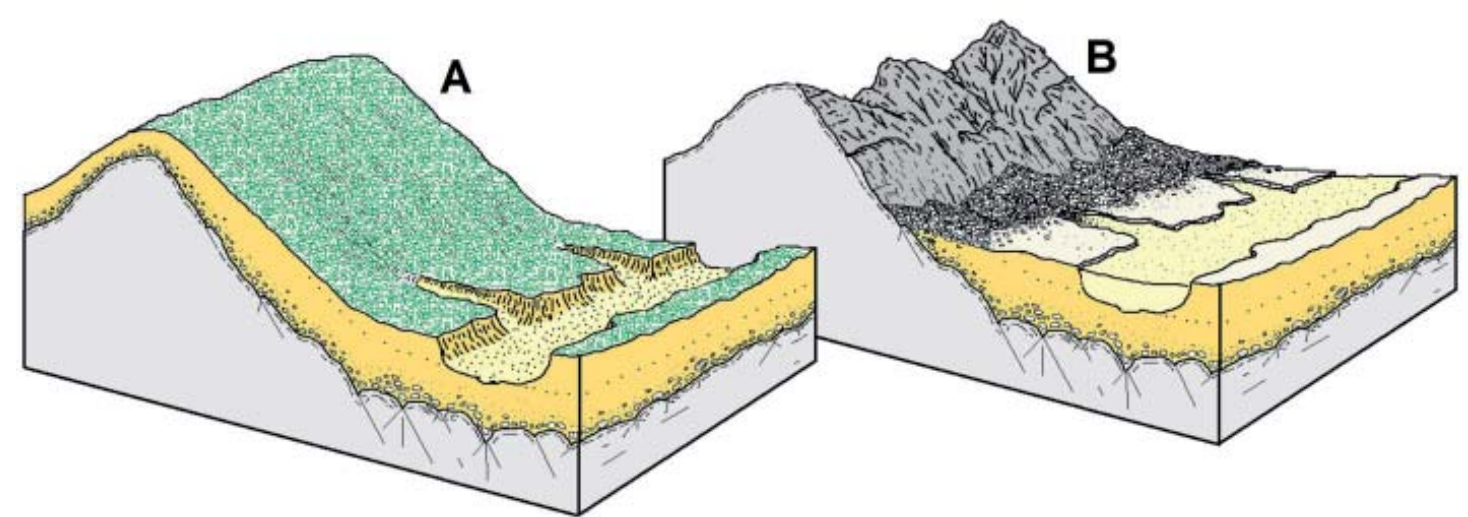

Figura 10 - Síntese evolutiva baseada na remoção de manto de alteração e exposição do embasamento na passagem de um clima úmido para seco. A - Clima úmido favorece a alteração em profundidade originando espessos regolitos. $B-A$ passagem para o clima seco resulta na retomada da erosão e exposição do embasamento. (Elaborado a partir das concepções sobre a evolução do relevo de Bigarella, 2003). 
O embasamento granítico exposto uma vez submetido ao progressivo aprofundamento diferencial do front de alteração, associado à erosão superficial, faz com que os setores da superfície basal de intemperismo que não sofreram alteração sejam gradativamente alçados à superfície (VITTE, 2005). Dentre os motivos que podem gerar esse alçamento pode-se destacar a ausência de fraturas e/ou a diferenciação faciológica do embasamento.

A esse respeito Torquato et al. (1988) elencou que a diferenciação de fácies graníticas em escala regional pode exibir um certo comportamento geomorfológico. Assim, a principal evidencia geomorfológica de um comportamento seletivo das fácies graníticas em relação a ação erosiva é derivada da ocorrência de inselbergues agrupados ou não. Em um ambiente semiárido em que os processos de intemperismo termoclástico predominam, algumas propriedades das rochas graníticas devem ser consideradas para demonstrar o seu comportamento geomorfogenético. Dentre as propriedades capazes de justificar a ocorrência de relevos residuais são discerníveis as seguintes:

1 - Escassez de biotita - aumenta a coerência da rocha resistindo a dilatação; os planos de esfoliação se mantem unidos e a biotita se torna menos alterável. 2 - Escassez de plagioclasios e maior proporção de microclina. 3 Maior proporção de quartzo. 4 - Escassez de diaclases. 5 - Pouca porosidade. 6 - Meio não salino.

O granito da fácies Quixadá, que compõem o batólito homônimo, está entre os que possuem a maioria das condições aludidas, justificando a maior concentração de inselbergues. As demais fácies podem eventualmente condicionar a presença de relevos residuais, embora com maior espaçamento entre eles (TORQUATO et al., 1988).

De modo distinto ao trabalho de Torquato et al. (1988), que fez considerações sobre o comportamento geomorfológico de fácies do embasamento em uma escala regional, este trabalho analisa os diferentes padrões de inselbergues dentro uma mesma unidade litológica (Quixadá) que compõem o batólito homônimo.

Sobre a gênese da variabilidade faciológica no âmbito do batólito Quixadá, Almeida et al. (1999) afirmam que as associações litológicas são produtos de mistura de magmas. Os enclaves magmáticos encontrados neste batólito possuem mineralogia e química indicando que os líquidos originais tinham composição basáltica e que estes basaltos, como indicam os inúmeros diques sinplutônicos foram injetados em um líquido de composição mais ácida, em vários estágios de sua cristalização levando a hibridização química. A esse respeito, Neves (2012) afirmou que a diferenciação de magmas basálticos pode produzir líquidos de composição granítica.

Essa variabilidade faciológica dentro de uma mesma unidade litológica pode explicar a diversidade de formas que os inselbergues assumem, sobretudo dos tipos 1 e 2. As feições que os caracterizam seriam assim a resposta geomorfológica da composição das fácies a evolução morfoclimática. Já a origem dos inselbergues, resulta das diferenciações da intensidade da deformação, seja de natureza rúptil, pós intrusão, seja de natureza dúctil e portanto sin-plutônica. Os eventos deformacionais originam feições estruturais do tipo foliação/fraturamento que favorecem a intemperização termoclástica, uma vez que a lineação dos minerais constituem uma zona preferencial para a propagação de fraturas. O embasamento fraturado facilita a saprolitização originando uma zona pedogênica. Na passagem de um clima mais úmido para um mais seco, a redução da umidade resulta na expansão de sistemas florísticos caducifólios com mais espassamento e menor capacidade de proteção do manto de alteração. A erosão se processa removendo as frações mais finas resultando na exposição do saprólito. Esse processo resulta em relevos saprolíticos, por vezes do tipo Tor de granito, onde blocos soltos parcialmente alterados são expostos em superfície. Assim, a remoção dos detritos friáveis resultantes das alternâncias entre os ciclos erosivos originará os inselbergues por meio da erosão diferencial.

\section{Conclusões}

As conclusões obtidas por esse trabalho sugerem para o campo de inselbergues de Quixadá, uma origem associada à ação conjunta de fatores de ordem estrutural (trend de lineamentos), litológica (variabilidade faciológica do granito) e paleoclimática (alternância entre fases denudacionais). A análise do trend de lineamentos dúcteis sin-plutônicos e rúpteis relacionados às fraturas revelou que o papel exercido por essas estruturas foi responsável pela alteração diferencial da rocha segundo a densidade do fraturamento. Esses lineamentos possuem direção preferencial NE-SW e estão geneticamente associados às zonas de cisalhamento dúcteis pré-cambrianas Senador Pompeu e Quixeramobim. Os dados 
relativos à distribuição geográfica dos inselbergues e dos lajedos associados aos trends de lineamentos apontam para uma maior concentração de exposições graníticas nas áreas com as menores densidades de lineamentos. Tal característica resultará em uma alteração saprolítica diferencial segundo a densidade do fraturamento, condicionando a formação de mantos de alteração mais espessos nas áreas mais fraturadas e portanto mais susceptíveis a meteorização. Nestas áreas além do trend de fraturas, os planos de foliação aumentam a susceptibilidade da rocha ao fraturamento termoclástico acelerando a saprolitização. Essa distribuição diferencial dos trends de lineamentos associados ao quadro de variabilidade climática imprimiu fases pedogênicas e erosivas que possibilitaram a progressiva exumação dos núcleos granitoides menos fraturados. O relativo alçamento da paleosuperfície granítica ocorreu segundo o modelo de Echtplanação de Budel (1982), originando as elevações residuais denominadas inselbergues. A morfologia associadas a cada uma dessas elevações está diretamente relacionada à sua composição, sobretudo a relação percentual entre Quartzo, Feldspatos e Biotita no interior das fácies graníticas que compõem o batólito Quixadá.

\section{Agradecimentos}

Agradecemos ao Prof. Jean Pierre Peulvast (Universidade de Paris Sorbonne IV) pela revisão crítica deste trabalho.

\section{Referências Bibliográficas}

AB SÁBER, A. N. Participação das superfícies aplainadas nas paisagens do Nordeste Brasileiro. IGEOG-USP, Bol. Geomorfologia, São Paulo, SP, n. 19, p 38, 1969.

ANDRADE G.O; LINS R. (1965). Introdução à Morfoclimatologia do Nordeste do Brasil. Arquivos do Instituto de Ciências da Terra, Recife, n. (3-4), p. 11-28, 1965.

AlmeidA, A.R. Petrologia e Aspectos Tectônicos do Complexo Granítico Quixadá-Quixeramobim - CE. 1995. 279 f. Tese (Doutorado em Geociências)- Instituto de Geociências, Universidade de São Paulo. São Paulo, 1995.

ALMEIDA, A.R; ULBRICH, H.G.J; MCREATH, I. O Batólito Quixadá - Petrologia e Geoquímica. Revista de Geologia UFC, Fortaleza, CE, n. 12, p. 29-52, 1999.

ALMEIDA, A.R; ULBRICH, H.G.J. O Batólito Granítico Quixeramobim-Ce. - Aspectos estruturais internos e mecanismo de alojamento crustal. Revista de Geologia UFC, Fortaleza, CE, 2003.

ARTHAUD, M.H. Evolução Neoproterozóica do Grupo Ceará (Domínio Ceará Central, NE Brasil): da sedimentação à colisão continental brasiliana. 2007. 170 f. Brasília, 2007. Tese (Doutorado em Geociências)- Instituto de Geociências da Universidade de Brasília. Brasília, 2007.

BIGARELlA, J. J. Estrutura e Origem das Paisagens Tropicais. Vol.1. Florianópolis: Ed. UFSC, 1994.

BIGARELlA, J. J. Estrutura e Origem das Paisagens Tropicais. Vol.3. Florianópolis: Ed. UFSC, 2003.

BRASIL. Levantamento de Recursos Naturais. Projeto Radam Brasil - Folha Jaguaribe/Natal. Vol. 23. Rio de Janeiro, 1981.

BRITO NEVES, B.B., SANTOS, E. J., VAN SCHMUS, W. R. Tectonic history of the Borborema Province, northeastern Brazil. In: Cordani, U.G., Milani, E.J., Thomaz Filho, A., Campos, D.A. (Eds.). Tectonic Evolution of South America. Rio de Janeiro, 31 International Geological Congress, 2000. p. 151-182.

BUDEL, J. Climatic Geomorphology. New Jersey. Princeton University Press, 1982.

CASTRO, D.L; CASTELO BRANCO, R.M.G; MARTINS, G; CASTRO, N.A; Radiometric, magnetic, and gravity study of the Quixadá batholith, central Ceará domain (NE Brazil): evidence for Pan-African/Brasiliano extension-controlled emplacement. Journal of South American Earth Sciences.Vol. v.15, n. 5, p.543-551, oct. 2002.

CAVALCANTE, A. Jardins suspensos no Sertão. Scientific American Brasil. v. 32, p. 69-73, 2005.

CORRÊA, A.C.B.; TAVARES, B.A. C.; MONTEIRO, K.A. Megageomorfologia e morfoestrutura do Planalto Borborema. Revista do Instituto Geológico, São Paulo, v. 31, p. 35-52, 2010.

CPRM. Atlas digital de geologia e recursos minerais. Mapas na escala 1:500,000. Serviço Geológico do Brasil -CPRM (digital midia) 2003.

EBERT, K; HÄTTESTRAND, C. The impact of Quaternary glaciations on inselbergs in northern Sweden. Geomorphology, Amsterdam, v.115, n.1, p. 56-66, 2010.

FETTER, A.H.; SCHMUS, W.R.V.; SANTOS, T.J.S.; NETO, J.N.N.; ARTHAUD, M.H. 4 UPb and Sm-Nd geochronological constraints on the crustal evolution and basement architecture of Ceará State, NW Borborema Province, NE Brazil: implications for the existence of the Paleoproterozoic Supercontinent “Atlantica”. Revista Brasileira de Geociências, São Paulo, v. 
30, n. 1, p. 102-106, 2000.

GOMES, P; ALVES, M. Floristic And Vegetational Aspects Of An Inselberg In The Semi-Arid Region Of Northeast Brazil. Edinburgh Journal Of Botany, 66 (2), p. 329-346, 2009.

GOUDIE, A.S. Encyclopedia of Geomorphology. V. 1. IAG, International Geomorphology Union, 2004.

GURGEL, S. P. P. ; BEZERRA, F. H. R. ; CORRÊA, A. C.B. ; MARQUES, F O. ; MAIA, R. P. . Cenozoic uplift and erosion of structural landforms in NE Brazil. Geomorphology . Amsterdam, v. 186, p. 68, 2013.

INMET, Dados históricos/Clima, Instituto Nacional de Meteorologia, 2014. Disponível em: www.inmet.gov.br.

JACOBS, M.G. Enclaves microgranulares máficos em rochas híbridas associadas com os granitoides da suíte encruzilhada do sul - RS. 2012. Monografia (Graduação em Geologia)Instituto de Geociências da Universidade Federal do Rio Grande do Sul, porto Alegre, 2012.

KING, L. C. A Geomorfologia do Brasil Oriental. Revista Brasileira de Geografia. v. 18, n. 2, p. 147-265, 1956.

MABESOONE, J. M; CASTRO, C. Desenvolvimento geomorfológico do Nordeste Brasileiro. Boletim do Núcleo Nordeste da Sociedade Brasileira de Geologia. v. 3. p. 3-5.1975.

MAIA, R. P.; BEZERRA, F. H. ; SALES, V. C. Geomorfologia do Nordeste: Concepções clássicas e atuais acerca das superfícies de aplainamento. Revista de Geografia (Recife), v. 27, p. -6-19. 2010.

MAGINI, C \& HACKSPACHER P.C. Geoquímica e ambiência tectônica do arco magmático de Pereiro, região NE da Província Borborema. Revista Brasileira de Geociências, v 38, n. 2, p. 336-355, 2008.

MATMON, A; MUSHKIN, Y; ENZEL, T; GRODEK, ASTER, T. Erosion of a granite inselberg, Gross Spitzkoppe, Namib Desert. Geomorphology, Amsterdam, v. 201, p. 52-59, 2013.

MORAES NETO, J.M; GREEN, P.F; KARNER, G.D; ALKMIN, F.F. Age the of Serra dos Martins Formations, Borborema Plateau, northeastern Brazil: Constraints from apatite and zircon fission track analysis. Boletim de Geociências da Petrobras, v. 16, p. 23-52, 2008.

NEVES, S.P; Granitos Orogênicos: da geração dos magmas à intrusão e deformação. Rio de Janeiro: Synergia, 2012.

NIMER, E. Climatologia do Brasil. Rio de Janeiro: Instituto Brasileiro de Geografia e Estatística, 1989.
NOBRE, P. Clima e Mudanças Climáticas no Nordeste. Projeto Áridas, Ministério da Integração Nacional, v. 1, n.1, 1994.

NOGUEIRA, J.F. Caracterização geométrica e Deformacional do Batólito de Quixadá, CE. 1998. Dissertação (Mestrado em Geologia)- Instituto de Geociências e Ciências Exatas da Universidade Estadual Paulista, Rio Claro 1998.

NOGUEIRA, J.F. Estrutura, geocronologia e alojamento dos batólitos de Quixadá, Quixeramobim e Senador Pompeu - Ceará Central Tese (Doutorado em Geologia)- Instituto de Geociências e Ciências Exatas da Universidade Estadual Paulista. Rio Claro, 2004.

OSBORNE, G. Evolution of the late cenozoic inselberg landscape of southwestern Jordan. Paleogeography, Paleoclimatology, Paleoecology. 49, 1-23, 1985

PEULVAST, J. P.; CLAUDINO SALES, V. Stepped Surfaces And Paleolandforms In The Northern Brasilian Nordeste: Constraints On Models Of Morfotectonic Evolution. Geomorphology, Amsterdam, v. 3, p. 89-122, 2004.

PEPIT, M. Geographie physique tropicale. Karthala, France, 1990.

POREMBSKI, S. Tropical inselbergs: habitat types, adaptive strategies and diversity patterns. Revista Brasileira de Botânica, São Paulo, v.30, n.4, p. 579-586, 2007.

ROMER, W. Differential weathering and erosion in an inselberg landscape in southern Zimbabwe: A morphometric study and some notes on factors influencing the long-term development of inselbergs. Geomorphology, Amsterdã, v86, p. 349-368, 2007.

SILVA, H.E. Alguns aspectos petrográficos e geoquímicos do Batólito Quixadá - Ceará. Revista Brasileira de Geociências. V.19, n.1, p. 101-107, 1989.

TARBUCK, E.J; LUTGENS, F.K. Earth Science. ed.11, New Jersey, USA: Person Prentice Hall, 2006.

TORQUATO, R.F.J (Coord); ALMEIDA, A.R; SIDRIM, A.C.G; MARANHÃO, C.M.L; PARENTE, C.V; TORQUATO, J.R.F; NETO, A.N; FILHO, J.F.A; SOUZA, J. V; SOUZA, M.J.N; ARTHAUD, M.H. Granitóides de Quixadá: Região de Quixadá e Solonópole. Revista de Geologia UFC, v. 2, n. 1⁄2, 1989.

TRINDADE, I.V; MARTINS SÁ, J; MACEDO, M.H.F; Comportamento de elementos químicos em rochas mineralizadas em ouro na Faixa Seridó, Província Borborema. Revista Brasileira de Geociências,

v.38, n.2, São Paulo, 2008 
TWIDALE, C.R.; VIDAL ROMANI J.R. On the multistage development of etch forms. Geomorphology, Amsterdam, v. 11, p. 107-124, 1994.

TWIDALE, C.R; The Two-Stage Concept Of Landform And Landscape Development Involving Etching: Origin, Development And Implications Of An Idea. Earth-Science Reviews, v. 57,p. 37-74, 2002.

VAN SCHMUS, W. R.; BRITO NEVES, B. B.; HACKSPACHER, P. C.; BABINSKI, M. U/Pb and Sm/Nd geochronologic studies of the eastern Borborema Province, Northeast Brazil: initial conclusions. Journal of South American Earth Sciences, v.
8, n. 3/4, p. 267-288, 1995.

VAUCHES, A., NEVES, S., CABY, R., CORSINI, M., EGYDIO-SILVA, M., ARTHAUD, M., AMARO, V., The Borborema shear zone system, NE Brazil. Journal of South American Earth Sciences, v. 8, n. 3/4, p. 247-266, 1995.

VIDAL ROMANÍ, J.R. \& YEPES TEMIÑO, J. Historia de la Morfogénesis Granítica. Caderno Laboratorio Xeolóxico de Laxe. Spain: A Coruña, v. 29, p. 331-360, 2004.

VITTE, A.C. Etchplanação dinâmica e episódica nos trópicos quentes e úmidos. Revista do Departamento de Geografia da USP, São Paulo, n. 16, p. 105-118, 2005. 